\title{
PENGARUH JUMLAH SAMPEL TERHADAP MODEL DAN BANGKITAN PERJALANAN DI KOTA RANTAU PADA PENELITIAN MANAJEMEN TRANSPORTASI
}

\author{
Noor Jasmani \\ Dosen Prodi Teknik Sipil Fakultas Teknik Sipil dan Perencanaan \\ Universitas Nahdlatul Ulama Kalimantan Selatan \\ E-mail: jasmani23@yahoo.co.id /HP.+6282148542526
}

\begin{abstract}
ABSTRAK
Penelitian ini mengenai permodelan bangkitan perjalanan dengan ukuran sampel yang bervariasi, yaitu 50\%, 75\% dan 100\% dengan metode analisa regresi linear. Tujuan dari penelitian ini adalah untuk membuat model bangkitan perjalanan terkait dengan jumlah ukuran sampel dan untuk mengetahui pengaruh ukuran sampel tersebut terhadap model dan hasil bangkitan perjalanan. Penelitian ini dilakukan dengan cara pendataan langsung dengan menggunakan kuesioner, yang diisi secara langsung mandiri oleh responden maupun dengan bantuan petugas survei. Penelitian ini dilakukan di kota Rantau Kabupaten Tapin dengan cara sampel acak sejumlah 756 rumah tangga yang tersebar di 11 kecamatan. Pengujian dilakukan pada faktor sosial ekonomi seperti jumlah anggota rumah tangga, pendapatan rumah tangga, kepemilikan sepeda motor dan kepemilikan mobil. Kemampuan model untuk menjelaskan variasi yang terjadi diukur dengan koefisien determinasi dengan rentang 0,911 sampai dengan 1,000. Jumlah model bangkitan perjalanan yang terbaik ada 3 buah dari 11 buah model yang terpilih, dengan populasi yang mendominasi model tersebut ( $y=a+b$. populasi). Semakin sedikit jumlah sampel yang diambil menyebabkan bertambahnya nilai koefisien $a$ dan $b$, juga $y$. Dengan uji perbandingan Kruskal-Wallis dapat dibuktikan bahwa ukuran sampel tidak begitu mempengaruhi perubahan nilai koefisien $a$ dan $b$ maupun jumlah bangkitan perjalanan.
\end{abstract}

Kata Kunci: Analisa regresi, ukuran sampel, model bangkitan perjalanan dan uji Kruskal Wallis

\begin{abstract}
This research is about trip generation modeling with various sample sizes, namely 50\%, $75 \%$ and $100 \%$ with linear regression analysis method. The purpose of this study is to create a trip generation model related to the number of sample sizes and to determine the effect of this sample size on the trip generation model and results. This research was conducted by direct data collection using a questionnaire, which was filled in directly independently by the respondents or with the assistance of survey officers. This research was conducted in the city of Rantau, Tapin Regency by means of a random sample of 756 households spread over 11 districts. The test is carried out on socio-economic factors such as the number of household members, household income, motorcycle ownership and car ownership. The model's ability to explain the variations that occur is measured by the coefficient of determination ranging from 0.911 to 1,000. The best number of trip generation models is 3 out of 11 selected models, with a population that dominates the model $(y=a+b$. Population). The smaller the number of samples taken causes an increase in the value of the coefficients $a$ and $b$, also $y$. With the Kruskal-Wallis comparison test, it can be proven that the sample size does not really affect the changes in the value of the coefficients $a$ and $b$ or the number of trip generation.
\end{abstract}

Keywords: Regression analysis, sample size, trip generation model and Kruskal Wallis test 


\section{PENDAHULUAN}

\section{Latar Belakang}

Pada suatu proses permodelan, ketepatan model sangat tergantung pada jumlah (ukuran) sampel yang diambil. Semakin sedikit jumlah sampel yang diambil akan memerlukan biaya yang lebih sedikit, tetapi akan menghasilkan model yang kurang baik. Sedangkan semakin banyak jumlah sampel yang diambil akan menghasilkan model yang lebih baik (mendekati ketepatan), tetapi akan memerlukan biaya yang lebih mahal, surveyor yang lebih banyak dan waktu proses yang cukup lama. Disini penulis mencoba melakukan studi pengaruh ukuran sampel terhadap model dan hasil bangkitan perjalanan (Trip Production) untuk mencari alternatif yang terbaik.

\section{Perumusan Masalah}

Berdasarkan latar belakang tersebut diatas maka permasalahan yang dapat dirumuskan adalah:

1. Seperti apakah model bangkitan perjalanan dengan terkait dengan variasi ukuran sampel?

2. Bagaimana pengaruh ukuran sampel tersebut terhadap model dan hasil bangkitan perjalanan?

\section{Tujuan Penelitian}

Tujuan dari penelitian ini adalah:

1. Menyusun beberapa buah model bangkitan perjalanan terkait dengan variasi ukuran sampel.

2. Mengetahui pengaruh ukuran sampel terhadap model dan hasil bangkitan perjalanan.

\section{Batasan Masalah}

Untuk memudahkan dalam menyelesaikan penelitian ini, maka dirasa perlu untuk melakukan pembatasan mengenai ruang lingkup pada penelitian ini. Adapun pembatasan mengenai ruang lingkup tersebut adalah:

1. Variabel yang digunakan dalam model bangkitan perjalanan ini adalah populasi, pendapatan, kepemilikan sepeda motor dan kepemilikan mobil sebagai variabel bebas sedangkan jumlah perjalanan sebagai variabel tidak bebas.

2. Pendapatan yang digunakan untuk memperkirakan jumlah Bangkitan Perjalanan di wilayah kota Rantau adalah model regresi berganda (Multiple Regresi).

3. Wilayah penelitian ini adalah wilayah perkotaan saja, meliputi satu kota yaitu kota yang terdiri atas 11 kecamatan.

\section{Pengertian Permodelan}

\section{TINJAUAN PUSTAKA}

Menurut Tamin (2000) Model adalah alat bantu atau media yang dapat digunakan untuk mencerminkan dan menyederhanakan suatu realita (dunia sebenarnya) secara terukur untuk mendapatkan tujuan tertentu, yaitu penjelasan dan pengertian yang lebih mendalam serta untuk kepentingan peramalan. 
Menurut Stopher (1980) bahwa konsep perencanaan transportasi telah berkembang dengan pesatnya dan yang populer saat ini adalah "Konsep Perencanaan Transportasi Empat Tahap". Konsep ini memiliki beberapa sub model yang masing-masing harus dilakukan secara terpisah dan sistematis, yaitu:

1. Bangkitan dan Tarikan Perjalanan (Trip Generation)

2. Sebaran Perjalanan (Trip Distributary)

3. Pemilihan Modal (Modal Split)

4. Pembebanan Rute (Trip Assignment)

\section{Model Bangkitan Perjalanan / Trip Generation}

Menurut Tamin (2000) ada beberapa definisi dasar mengenai model bangkitan perjalanan/Trip Generation sebagai berikut:

\section{Bangkitan Perjalanan / Trip Generation}

Bangkitan Perjalanan adalah tahapan permodelan untuk memperkirakan jumlah pergerakan yang berasal dari suatu zona atau tata guna lahan dan jumlah pergerakan yang tertarik ke suatu tata guna lahan atau zona. Pergerakan lalu-lintas merupakan fungsi tata guna lahan yang menghasilkan pergerakan lalu-lintas. Bangkitan lalu-lintas ini meliputi antara lain:

- Pergerakan yang meninggalkan suatu zona / trip production

- Pergerakan yang menuju ke suatu zona / trip attraction

\section{Perjalanan}

Perjalanan adalah pergerakan suatu arah dari zona asal ke zona tujuan, termasuk pergerakan berjalan kaki.

\section{Pergerakan Berbasis Rumah}

Adalah pergerakan yang salah satunya atau kedua zona (asal dan/atau tujuan) pergerakan tersebut adalah rumah/daerah pemukiman dan tempat tinggal.

\section{Penentuan Jumlah Sampel}

Menurut Tamin (2000)

Beberapa nilai sampel yang telah direkomendasikan untuk digunakan selama hampir 20 tahun.

\section{Menurut Pignataro (1973)}

Pignataro menyarankan beberapa ukuran sampel yang telah banyak digunakan untuk survei wawancara rumah tangga seperti terlihat pada Tabel 1.2 berikut:

Tabel 1.1. Rekomendasi Ukuran Sampel Survei Wawancara Rumah Tangga

\begin{tabular}{|c|c|}
\hline Populasi & $\begin{array}{c}\text { Ukuran Sampel } \\
\text { Rumah Tangga }\end{array}$ \\
\hline Dibawah 50.000 & $1: 5(20 \%)$ \\
\hline $50.000-150.000$ & $18(12,5 \%)$ \\
\hline $150.000-300.000$ & $1: 10(10 \%)$ \\
\hline $300.000-500.000$ & $1.15(6,7 \%)$ \\
\hline $500.000-1.000 .000$ & $1: 20(5 \%)$ \\
\hline Diatas 1.000 .000 & $1: 25(4 \%)$ \\
\hline
\end{tabular}

Sumber : Tamin (2000)
Tabel 1.2. Ukuran Sampel Survei Wawancara Rumah Tangga

\begin{tabular}{|c|c|c|c|c|}
\hline Populasi & \multicolumn{4}{|c|}{$\begin{array}{c}\text { Ukuran Sampel } \\
\text { (Rumah tangga) }\end{array}$} \\
\hline Dibawah 50.000 & 1 & 5 & 1 & 10 \\
\hline $50000-150000$ & 1 & 8 & $\mathrm{I}$ & 20 \\
\hline $150.000-300.000$ & $\mathrm{I}$ & 10 & 1 & 35 \\
\hline $300.000-500.000$ & 1 & 15 & 1 & 50 \\
\hline $500.000-1.000 .000$ & 1 & 20 & 1 & 70 \\
\hline Diatas 1.000.000 & 1 & 25 & 1 & 100 \\
\hline
\end{tabular}

Sumber : Pignataro (1973) 


\section{Faktor Yang Mempengaruhi Pergerakan Manusia}

Menurut Tamin (2000) berdasarkan pada beberapa kajian yang telah dilakukan sebaiknya hal berikut perlu dipertimbangkan dalam permodelan bangkitan pergerakan, yaitu Penghasilan keluarga, Kepemilikan kendaraan, Struktur rumah tangga, Ukuran rumah tangga, Kepadatan daerah pemukiman dan Aksesibilitas.

\section{Analisa Regresi}

Menurut Walpole (1995), Hubungan antara peubah bebas dan respon, yang dicocokkan dengan data hasil pengamatan, ditandai dengan persamaan prediksi yang disebut persamaan regresi. Bila $Y$ dan $X$ masing-masing tunggal, persoalannya menjadi regresi $Y$ atas $X$. Bila ada $k$ peubah bebas, maka dikatakan regresi $Y$ atas $X_{1}, X_{2}, \ldots, X_{k}$. Istilah regresi linear berarti, bahwa rataan $\mu y \mid x$ mempunyai hubungan (berkaitan) linear dengan $x$ dalam bentuk linear populasi:

$$
\mu y \mid x=\alpha+\beta x
$$

Koefisien regresi $\alpha$ dan $\beta$ merupakan dua parameter yang akan ditaksir dari data terok (sampel). Bila taksiran untuk kedua parameter itu masing-masing dinyatakan dengan a dan $\mathrm{b}$ maka $\mu y$ dapat ditaksir dengan $y$ dari bentuk garis regresi berdasarkan terok (sampel) atau garis kecocokan regresi: $Y=a+b x$.

\section{Regresi Linear Sederhana}

Dalam hal regresi linear sederhana, hanya akan terdapat satu peubah bebas $x$ dan satu peubah tidak bebas $Y$, datanya dapat disajikan sebagai pasangan pengamatan $\left\{\left(x_{i}, y_{i} ; i=1,2, n\right\}\right.$. Bila dimisalkan bahwa semua rataan $\mu y \mid X i$ terletak pada satu garis lurus, maka tiap $Y i$ dapat ditulis sebagai model regresi linear sederhana seperti berikut:

$$
Y i=\mu y \mid X i+E i=\alpha+\beta x i+E i
$$

dengan galat acak $E i$, sebagai galat model, haruslah mempunyai rataan nol.

Demikian juga, dengan menggunakan taksiran atau kecocokan garis regresi:

$$
\hat{y}=a+b x
$$

tiap pasangan pengamatan memenuhi:

$$
y i=a+b x_{i}+e_{i}
$$

sedangkan $e i=y_{i}-\hat{y}_{i}$, disebut sisa dan memberikan galat dalam kecocokan model pada titik data ke $i$.

\section{Menaksir koefisien $a$ dan $b$}

Jumlah Kuadran Galat terhadap garis regresi dan dinyatakan dengan JKG. Cara untuk menaksir parameter dinamakan metode kuadrat terkecil. Jadi $a$ dan $b$ akan dicari sehingga meminimumkan:

$$
\mathrm{JKG}=\sum_{i=1}^{n} e i^{2}=\sum_{i=1}^{n} y_{i}-\hat{y}_{i}=\sum_{i=1}^{n}\left(y_{i}-a-b x_{i}\right)^{2}
$$

Bila JKG diturunkan terhadap $a$ dan $b$ maka diperoleh:

$$
\frac{\partial(J K G)}{\partial b}=-2 \sum_{i=1}^{n}\left(y_{i}-a-b x_{i}\right) \quad \frac{\partial(J K G)}{\partial b}=-2 \sum_{i=1}^{n}\left(y_{i}-a-b x_{i}\right) \cdot x_{i}
$$


Bila kedua persamaan diatas disamakan dengan nol kemudian disusun kembali maka diperoleh persamaan (disebut persamaan normal):

$$
N a+b \sum_{i=1}^{n} x_{i}=\sum_{i=1}^{n} y_{i} \Rightarrow a \sum_{i=1}^{n} x_{i}+b \sum_{i=1}^{n} x_{i}^{2}=\sum_{i=1}^{n} x_{i} \cdot y_{i}
$$

Yang akan menghasilkan rumus perhitungan untuk a dan $b$ :

$$
b=\frac{n \sum_{i=1}^{n} x_{i} \cdot y_{i}-\left(\sum_{i=1}^{n} x_{i}\right) \cdot\left(\sum_{i=1}^{n} y_{i}\right)}{n \sum_{i=1}^{n} x_{i}^{2}-\left(\sum_{i=1}^{n} x_{i}\right)^{2}} \quad \text { dan } \quad a=\frac{\sum_{i=1}^{n} y_{i}-b \sum_{i=1}^{n} x_{i}}{n}
$$

\section{Koefisien Korelasi $r$}

Menurut Walpole (1995), Koefisien korelasi ini digunakan untuk mengukur eratnya linear antara dua peubah, yaitu $\mathrm{x}$ dan $\mathrm{y}$. Koefisien korelasi ini dapat dihitung dengan cara sebagai berikut ini:

$$
r=b . \sqrt{ }\left(J_{x x} / J_{y y}\right)=J_{x y} / J_{x x} . J_{y y} \rightarrow \text { nilai } r(-1 \leq r \leq n)
$$

\section{Koefisien Penentu $\left(r^{2}\right)$}

Menurut Walpole (1995), bahwa koefisien penentu menyalakan proporsi variasi $J_{y y}$ yang diterangkan oleh regresi $Y$ pada $X$, yakni $J K R$. Jadi $r^{2}$ menyatakan proporsi variasi keseluruhan dalam nilai peubah $Y$ yang dapat diterangkan atau diakibatkan oleh hubungan linear dengan nilai peubah acak $X$.

$$
\left.r^{2}=J_{x y}\right)^{2} / J_{x x .} J_{y y}=J K R / J K T \rightarrow 0 \leq r^{2} \leq 1
$$

\section{Regresi Linear Berganda}

Dalam hal $k$ peubah bebas $x_{1}, x_{2}, \ldots, x_{3}$, dari rataan $Y \mid x_{1}, x_{2}, \ldots, x_{k}$ diberikan oleh model linear regresi dari $b$ seperti berikut ini: $\mu y \mid x_{1}, x_{2}, \ldots, x_{k}=\beta_{0}+\beta_{1} x_{1}+\beta_{k} x_{k}$ dan taksiran respon diperoleh dari persamaan regresi terok (sampel):

$$
Y=b_{0}+b_{1} x_{1} \ldots .+b_{k} x_{k}
$$

Dalam rumus ini koefisien regresi $\beta i$ ditaksir dengan $b i$ dari data terok (sampel) dengan menggunakan metode kuadrat terkecil.

\section{Menaksir Koefisien Regresi}

Mencari taksiran kuadrat terkecil dari parameter $\beta_{0}, \beta_{1}, \ldots, \beta_{k}$ dengan mencocokkan model regresi linear darab (berganda): $\mu y \mid x_{1}, x_{2}, \ldots, x_{k}=\beta_{0}+\beta_{1} x_{1}+$ $\beta_{2} x_{2}+\ldots+\beta_{k} x_{k}$

Ketitik data: $\left\{\left(x_{1 i}, x_{2 i}, \ldots, x_{k i}\right) ; i=1,2, \ldots, n\right.$ dan $\left.n>k\right\}$, bila $y i$ adalah respon yang diamati pada nilai $x_{1 i}, x_{2 i}, \ldots, x_{k i}$ dari $k$ peubah bebas $x_{1}, x_{2}, \ldots, x_{k}$. Tiap pengamatan $\left(x_{1 i}, x_{2 i}, \ldots, x_{k i}, y_{i}\right)$ memenuhi persamaan dibawah ini:

$Y_{i}=\beta_{0}+\beta_{1} x_{1 i}+\beta_{2} x_{2 i}+\ldots+\beta_{k} x_{k i}+\varepsilon_{i}$ atau $y_{i}=b o+b_{1} x_{1 i}+b_{2}+x_{2 i}+\ldots+b_{k} x_{k i}+e_{i}$

Bila $\varepsilon_{i}$ dan $e_{i}$ masing-masing adalah galat acak dan sisa yang berkaitan dengan respon $y_{i}$. Dalam menggunakan metode kuadrat terkecil untuk menaksir $b_{0}, b_{1}, \ldots$, $b_{k}$, maka meminimumkan persamaan berikut:

$$
J K G=\sum_{i=1}^{n} e_{i}^{2}=\sum_{i=1}^{n}\left(y_{i}-b_{o}-b_{1} x_{1 i}-b_{2} x_{2 i}-b_{k} x_{k i}\right)^{2}
$$

Jika $J K G$ diturunkan berturut-turut terhadap $b_{0}, b_{1}, b_{2}, \ldots, b_{k}$, dan kemudian disamakan dengan nol, maka akan diperoleh seperangkat persamaan normal $k+1$ dibawah ini:

$n b o+b_{1} \sum_{i=1}^{n} x_{1 i}+b_{2} \sum_{i=1}^{n} x_{2 i}+\ldots+b_{k} \sum_{i=1}^{n} x_{k i}=\sum_{i=1}^{n} y_{i}$ 
bo $\sum_{i=1}^{n} x_{1 i}+b_{1} \sum_{i=1}^{n} x_{1 i}^{2}+b_{2} \sum_{i=1}^{n} x_{1 i} \cdot x_{2 i}+\ldots+b_{k} \sum_{i=1}^{n} x_{1 i} x_{k i}=\sum_{i=1}^{n} x_{1 i} \cdot y_{i}$

dan seterusnya sehingga didapat persamaan:

$$
\text { bo } \sum_{i=1}^{n} x_{k i}+b_{1} \sum_{i=1}^{n} x_{k i} \cdot x_{1 i}+b_{2} \sum_{i=1}^{n} x_{k i} \cdot x_{2 i}+\ldots+b_{k} \sum_{i=1}^{n} x_{k i}^{2}=\sum_{i=1}^{n} x_{k i} \cdot y_{i}
$$

persamaan ini dapat diselesaikan untuk $b_{0}, b_{1}, b_{2}, \ldots, b_{k}$ dengan menggunakan berbagai cara penyelesaian sistem persamaan linear.

\section{Koefisien Determinasi $\left(R^{2}\right)$}

Untuk melihat apakah suatu model regresi yang dicocokkan sudah memadai ialah

$$
R^{2}=\frac{\sum_{i=1}^{n}\left(y_{i}-y_{i}\right)^{2}}{\sum_{i=1}^{n}\left(y_{i}-\bar{y}_{l}\right)^{2}}=\frac{J K R}{J K T}
$$

\section{Uji f dan t-test}

Uji f-test dapat digunakan untuk mengetahui signifikansi suatu variabel terhadap terbentuknya suatu regresi model.

Uji-test dapat digunakan untuk menguji signifikansi nilai koefisien regresi. Setiap peubah yang mempunyai koefisien regresi yang tidak signifikan secara statistik harus dibuang dari model.

\section{Model Bangkitan Perjalanan Tipe Regresi}

Ada dua model bangkitan pergerakan yang berdasar analisa regresi yaitu model regresi berbasis zona dan model regresi berbasis rumah tangga.

\section{Model Regresi Berbasis Zona}

Model yang berupaya untuk menemukan hubungan linear antara jumlah pergerakan yang dibangkitkan atau tertarik oleh zona dan sosio-ekonomi rata-rata dari rumah tangga pada setiap zona. Model jenis ini akan menjelaskan variasi perilaku pergerakan antara zona.

\section{Model regresi berbasis rumah tangga}

Keragaman dalam suatu zona (intrazona) mungkin dapat dikurangi dengan jalan memperkecil luas zona, apalagi bila zona tersebut homogen. Namun, zona yang lebih kecil juga akan mempunyai kompleksitas permasalahan lebih besar dan mempunyai konsekuensi:

1. Model menjadi lebih mahal dalam hal pengumpulan data, kalibrasi, dan operasi;

2. Galat sampel menjadi lebih tinggi.

Cara mengelimir persoalan diatas, maka unit analisis yang paling sesuai adalah rumah tangga (bukan individu).

\section{Studi-Studi Tentang Model Bangkitan Pergerakan}

Beberapa studi tentang bangkitan pergerakan telah banyak dilakukan, baik yang berbasis keluarga maupun yang berbasis zona seperti contoh berikut ini.

\section{Berbasis Keluarga}

Menurut Isya (1998) ternyata ada dua variabel (peubah) bebas saja yang lebih cocok digunakan untuk permodelan yaitu jumlah anggota keluarga dan jumlah pemilikan kendaraan. Model regresi yang diperoleh adalah:

$$
Y=1,90988^{\prime} 7 X_{1},+1,139548 X_{2}-2,19463 \text {, dengan nilai } R^{2}=0,7912
$$


Karena studi tersebut hanya dilakukan pada satu kawasan perumahan yaitu Perumahan Kajhu, di Aceh Besar, sehingga belum mempresentasikan suatu model bangkitan pergerakan berbasis keluarga di suatu kota.

Menurut Mochammad Sigit Darmosudiharjo (1993), bahwa model bangkitan lalu lintas dari perumahan Antapani, Kodya Bandung sebagai berikut:
1. $T=1.6308 . P-1.0994$
2. $T=0.2049 . M+1.6276 . P-1.1299$
$R^{2}=0.7973$
3. $T=0.1708 . M+0.4162 . T I+2.622$
$R^{2}=0.7981$
4. $T=0.2026 . M+1.6256 . P+0.0376 . A-1.2696$
$R^{2}=0.0290$
5. $T=0.2585 . M+0.2869 . T I+0.5657 . A+0.6706$
$R^{2}=0.7959$
$R^{2}=0.0373$

Dimana:

$T=$ Total Perjalanan (perjalanan per rumah tangga)

$P=$ Anggota rumah tangga (orang)

$M=$ Pemilikan mobil (mobil)

$A=$ Usia (tahun)

$T I=$ Total pendapatan (rupiah)

\section{Berbasis Zona}

Menurut Tamin (2000), perhitungan bangkitan pergerakan dan tarikan pergerakan merupakan fungsi dari beberapa peubah sosio-ekonomi dan tata guna lahan. Terdapat tiga jenis bangkitan dan tarikan pergerakan yang diinginkan yaitu untuk penumpang, barang dan kendaraan. Beberapa peubah sosio-ekonomi dan tata guna lahan yang digunakan antara lain populasi, PDRB, PDRB Perkapita, luas industri, produksi pertanian, perkebunan dan perikanan. Contoh korelasi bangkitan perjalanan dengan peubah bebasnya untuk zona Jawa Timur, Jawa Tengah dan Jawa Barat dapat dilihat seperti dibawah ini.

1. Zona Jawa Timur

$$
\begin{array}{lll}
Y_{\text {Bangkitan Penumpang }} & =13,6368 \cdot X_{1}+21 \cdot 100,9 \cdot X_{2}-18.820 .746,5 & R^{2}= \\
0,6121 & R^{2}= \\
Y_{\text {Bangkitan Kendaraan }}=0,0110 \cdot X_{1}+18,4785 \cdot X_{2}-16 \cdot 967,8814 & \\
0,5851 & R^{2}= \\
Y_{\text {Bangkitan Barang }}=4,0526 \cdot X_{1}+7.902,21 \cdot X_{2}-6.368 \cdot 438,37 & \\
0,6348 &
\end{array}
$$

2. Zona Jawa Tengah

$$
\begin{array}{lll}
\text {Y}_{\text {Bangkitan Penumpang }}=18,500 \cdot X_{1}+4953,382 \cdot X_{2}-12 \cdot 071 \cdot 898,62 & R^{2}= \\
0,6121 & R^{2}= \\
\begin{array}{l}
\text { Yangkitan Kendaraan } \\
0,5851
\end{array} & R^{2}= \\
\begin{array}{l}
\text { Yangkitan Barang } \\
0,6348
\end{array} & =2,39005 \cdot X_{1}+2,1705 \cdot X_{1}+973,442,4869 &
\end{array}
$$

3. Zona Jawa Barat

$\begin{array}{lll}\text { Yangkitan Penumpang }_{\text {B }}=12,38 \cdot X_{1} & R^{2}= \\ \text { Yangkitan Kendaraan }=0,00 \cdot X_{1} & R^{2}= \\ 0,5851 & \\ Y_{\text {Bangkitan Barang }}=2,35 \cdot X_{1}+244,4363 \cdot X_{2}-2 \cdot 014 \cdot 293,0930 & R^{2}=\end{array}$
0,6348 
Dimana:

$X_{1}=$ Jumlah Penduduk

$X_{2}=$ PDRB per kapita (ribuan rupiah)

Terlihat bahwa Parameter jumlah Penduduk dan PDRB per-kapita merupakan peubah bebas yang dominan dalam menghasilkan bangkitan perjalanan.

\section{Desain Penelitian}

\section{METODE PENELITIAN}

Penulis mencoba menggunakan ukuran sampel yang berbeda, dengan tujuan untuk mengetahui ukuran sampel tersebut terhadap model serta hasil bangkitan perjalanan yang terjadi. Ukuran sampel tersebut adalah 50\%, $75 \%$ dan $100 \%$ dari jumlah sampel rumah tangga yang disurvei di wilayah studi.

Penulis membagi sampel rumah tangga disetiap zona tersebut menjadi 4 bagian, yaitu: $\mathrm{a}=25 \%$ bagian pertama, dibuat variasi untuk masing-masing ukuran sampul $\mathrm{b}=25 \%$ bagian kedua, $50 \%: 1 . \mathrm{a}+\mathrm{b} 2 . \mathrm{a}+\mathrm{c} 3 . \mathrm{a}+\mathrm{d} 4 . \mathrm{b}+\mathrm{c} 5 . \mathrm{b}+\mathrm{d} 6 . \mathrm{c}+\mathrm{d} \mathrm{c}=$ $25 \%$ bagian ketiga, $75 \%: 1 . a+b+c$ 2.b+c+d 3.+c+d+a $4 . d+a+b . d=25 \%$ bagian keempat, $100 \%: 1 . a+b+c+d$ ukuran sampel 100\%: $a+b+c+d$

Selanjutnya untuk setiap variasi ukuran sampel tersebut dibuat model bangkitan perjalanan sesuai dengan prosedur dibawah ini.

\section{Prosedur Penelitian}

\section{Alur Proses Permodelan Bangkitan Pergerakan Dengan Metode Analisa Regresi Linear}

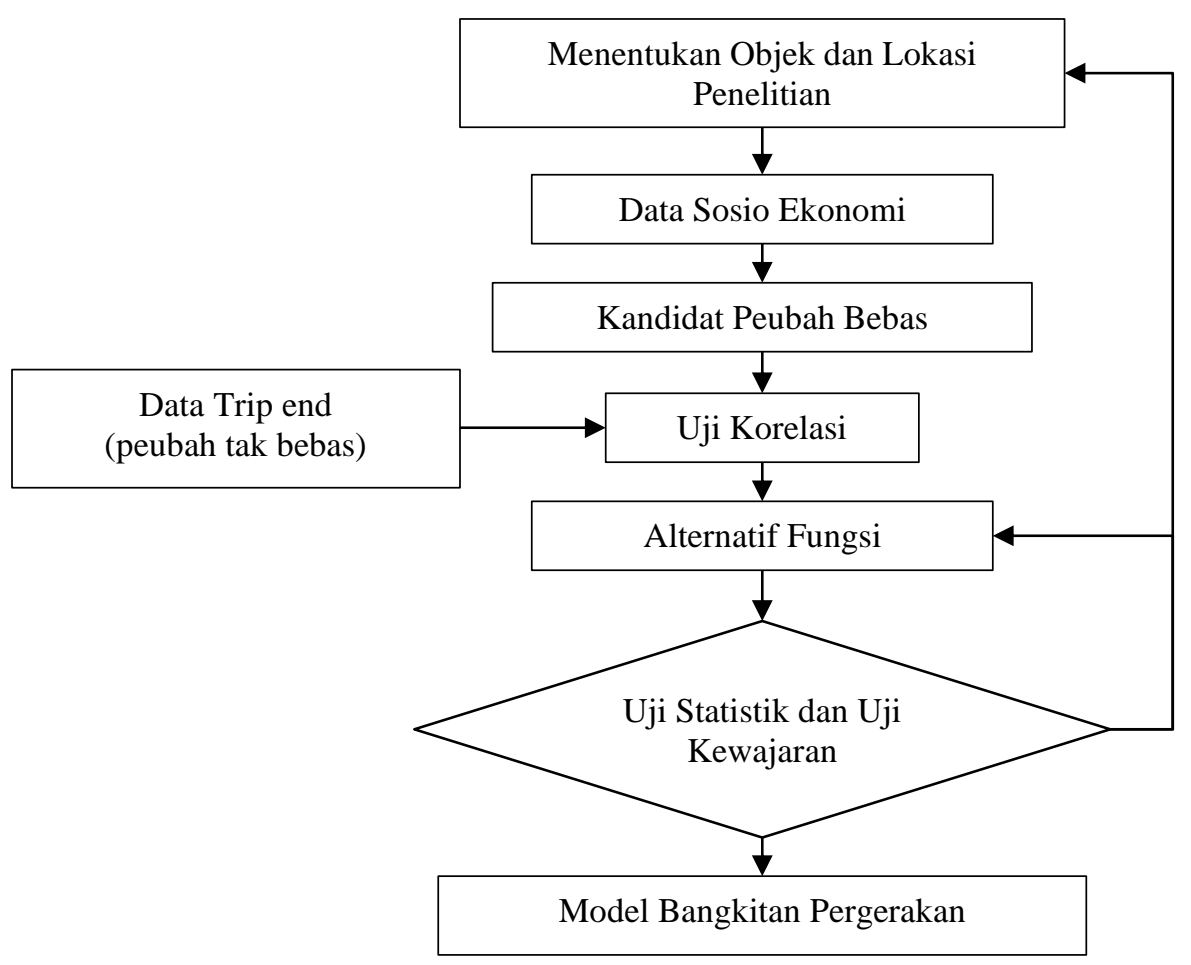




\section{PENGUMPULAN DATA}

\section{Lokasi Penelitian}

Lokasi yang diambil sebagai tempat penelitian adalah Kota Rantau Kabupaten Tapin terdiri dari 11 kecamatan. Lokasi atau daerah yang dipilih untuk penelitian adalah daerah perkotaan saja yang terdiri atas 11 kecamatan.

\section{Data Sekunder}

Adalah data pendukung dalam pelaksanaan penggalian data yang didapat dari kantor Biro Pusat Statistik (BPS) Kabupaten Tapin yang terdiri dari peta wilayah atau lokasi penelitian dan data kependudukan.

\section{Peta Lokasi Penelitian}

Dalam perencanaan dan pengembangan sarana dan prasarana transportasi disuatu daerah studi, biasanya diperlukan pembagian areal dalam daerah studi tersebut yang lazimnya disebut zona. Untuk mempermudah perencanaan ini maka diperlukan peta wilayah studi.

\section{Data Kependudukan}

Data jumlah penduduk dan jumlah rumah tangga disetiap zona kelurahan dapat dilihat pada Tabel 4.1. berikut:

Tabel 4.1. Data Kependudukan

Kabupaten Tapin

\begin{tabular}{|c|l|c|c|}
\hline No. & \multicolumn{1}{|c|}{ Zona } & $\begin{array}{c}\text { Jlh. } \\
\text { Penduduk }\end{array}$ & $\begin{array}{c}\text { Jlh. Rumah } \\
\text { Tangga }\end{array}$ \\
\hline 1 & Binuang & 30.008 & 7.752 \\
\hline 2 & Tapin Utara & 24.927 & 5.384 \\
\hline 3 & Tapin Selatan & 19.747 & 4.619 \\
\hline 4 & Tapin Tengah & 18.713 & 3.341 \\
\hline 5 & Candi Laras Utr. & 17.166 & 3.313 \\
\hline 6 & Candi Laras Sel & 12.891 & 3.097 \\
\hline 7 & B u n g u r & 12.869 & 1.132 \\
\hline 8 & Salam Babaris & 11.980 & 722 \\
\hline 9 & Lokpaikat & 9.709 & 359 \\
\hline 10 & Bakarangan & 9.329 & 347 \\
\hline 11 & Hatungun & 8.627 & 129 \\
\hline & Total & $\mathbf{1 7 5 . 9 6 6}$ & $\mathbf{3 0 . 1 9 5}$ \\
\hline
\end{tabular}

Sumber: BPS Kabupaten Tapin 2019
Tabel 4.2. Jumlah Rumah Tangga yang Disurvei di 11 Kecamatan

\begin{tabular}{|c|l|c|}
\hline No. & \multicolumn{1}{|c|}{ Kelurahan } & $\begin{array}{c}\text { Jlh rmh } \\
\text { tg disurvei }\end{array}$ \\
\hline 1 & Binuang & 196 \\
\hline 2 & Tapin Utara & 132 \\
\hline 3 & Tapin Selatan & 116 \\
\hline 4 & Tapin Tengah & 84 \\
\hline 5 & Candi Laras Utr. & 80 \\
\hline 6 & Candi Laras Sel & 76 \\
\hline 7 & B u n g u r & 28 \\
\hline 8 & Salam Babaris & 20 \\
\hline 9 & Lokpaikat & 8 \\
\hline 10 & Bakarangan & 8 \\
\hline 11 & Hatungun & 8 \\
\hline & Jumlah & $\mathbf{7 5 6}$ \\
\hline
\end{tabular}

\section{Data Primer}

Adalah data yang diperoleh dari penyebaran format wawancara rumah tangga atau kuesioner ke setiap rumah tangga yang disurvei, yang terdiri dari data sosiaekonomi seperti jumlah anggota rumah tangga, jumlah pendapatan rumah tangga, serta jumlah kepemilikan sepeda motor dan mobil pribadi di setiap rumah tangga sebagai variabel bebas. Sedangkan sebagai variabel tak bebasnya adalah jumlah perjalanan yang dilakukan setiap anggota rumah tangga.

\section{Jumlah Sampel}

Dari data pada Tabel 4.1., diketahui jumlah penduduk kota Rantau adalah 136.542 orang. Berdasarkan rekomendasi ukuran sampel survei wawancara rumah tangga seperti pada tabel 2.1, maka jumlah rumah tangga yang disurvei adalah antara 1 : 
20 sampai dengan $1: 8$, yaitu antara 1.510 sampai dengan 3.775 rumah tangga. Penulis mencoba dengan sampel 50\% dari batas minimum, yaitu sebanyak 756 rumah tangga dengan rincian lengkap seperti pada tabel 4.2.

\section{Kuesioner}

Adalah panduan untuk pelaksanaan tanya jawab disetiap rumah tangga yang diambil sebagai sampel pada penelitian ini.

1. Karakteristik Rumah Tangga

Berisi daftar jumlah anggota keluarga, kepemilikan kendaraan dan pendapatan.

2. Karakteristik Perjalanan

Berisi asal dan tujuan dari setiap perjalanan, modal yang digunakan dan waktu yang digunakan untuk memulai dan mengakhiri perjalanan, serta maksud dan tujuan perjalanan responden.

\section{Pelaksanaan Survei}

Dimulai dari akhir Januari sampai dengan pertengahan Maret 2003.

Pelaksanaan pengisian kuesioner ini dengan dua cara, yaitu :

1. Daftar isian ditinggal setiap rumah tangga sesuai dengan jumlah anggota keluarganya.

2. Diisi langsung oleh petugas survei.

\section{Rekapitulasi Data}

Rekapitulasi data hasil survei wawancara 756 rumah tangga yang tersebar di 11 zona dapat dilihat pada Lampiran 3, dan contoh rekap data untuk ukuran sampel $100 \%$ untuk masing- masing zona dapat dilihat pada tabel 4.3. berikut ini.

Tabel 4.3. Rekap Data Ukuran Sampel $100 \%$

\begin{tabular}{|c|l|c|c|c|c|c|}
\hline \multirow{2}{*}{ No. } & \multirow{2}{*}{ Kecamatan } & Populasi & Pendapatan & \multicolumn{2}{|c|}{ Kendaraan } & Perjalanan \\
\cline { 3 - 6 } & & orang & 1.000 .000 & Spdmtr & mobil & perjalanan \\
\hline 1 & Binuang & 796 & 296.95 & 165 & 56 & 511 \\
\hline 2 & Tapin Utara & 504 & 198.75 & 124 & 37 & 309 \\
\hline 3 & Tapin Selatan & 454 & 185.85 & 133 & 21 & 281 \\
\hline 4 & Tapin Tengah & 353 & 146.16 & 103 & 18 & 205 \\
\hline 5 & Candi Laras Utr. & 298 & 98.65 & 69 & 21 & 190 \\
\hline 6 & Candi Laras Sel & 288 & 114.40 & 82 & 23 & 186 \\
\hline 7 & B u n g u r & 112 & 28.65 & 23 & 8 & 73 \\
\hline 8 & Salam Babaris & 83 & 18.65 & 13 & 5 & 52 \\
\hline 9 & Lokpaikat & 37 & 4.95 & 4 & 1 & 20 \\
\hline 10 & Bakarangan & 33 & 6.00 & 6 & 2 & 23 \\
\hline 11 & Hatungun & 31 & 3.15 & 2 & 0 & 9 \\
\hline
\end{tabular}

\section{HASIL DAN PEMBAHASAN}

\section{Model Bangkitan Perjalanan}

Untuk mempermudah proses permodelan bangkitan perjalanan ini digunakan program SPSS v.11, dengan dua buah metode yaitu Step Wise dan Enter (lihat Lampiran 5) dengan tujuan sebagai bahan pertimbangan atau perbandingan untuk memilih model yang terbaik. 


\section{Ukuran Sampel $100 \%$}

Hasil permodelan bangkitan perjalanan dengan ukuran sampel $100 \%$ dengan metode Enter dan Step Wise dapat dilihat pada tabel 5.1. dan Tabel 5.2 berikut ini:

Tabel 5.1. Beberapa Model Bangkitan Perjalanan Dengan Metode Enter

\begin{tabular}{|c|l|c|c|c|}
\hline No. & \multicolumn{1}{|c|}{ Model Bangkitan Perjalanan } & $\mathbf{R}^{\mathbf{2}}$ & SEE & F \\
\hline 1 & Y = -3.666+ 0.635.P & 0.998 & 8.021 & 3770.220 \\
\hline 2 & Y - 11.892+ 0.157.I & 0.983 & 21.479 & 518.042 \\
\hline 3 & Y = 2.596+ 2.528.S & 0.933 & 42.600 & 124.987 \\
\hline 4 & $Y=14.686+8841 . \mathrm{M}$ & 0.959 & 33.369 & 209.373 \\
\hline 5 & $\begin{array}{l}\text { Y }=-8.857+0.806 . P-0.066 .1 \\
+0.119 . S+0.607 . M\end{array}$ & 0.999 & 6.773 & 1323.663 \\
\hline
\end{tabular}

Tabel 5.2. Model Bangkitan Perjalanan Dengan Metode Step Wise

\begin{tabular}{|c|c|c|c|c|}
\hline No. & Model Bangkitan Perjalanan & $\mathbf{R}^{\mathbf{2}}$ & SEE & F \\
\hline 1 & $\mathrm{Y}=-3.666+0.635 . \mathrm{P}$ & 0.998 & 8.021 & 3770.220 \\
\hline
\end{tabular}

Dimana :

$\mathrm{Y}=$ Jumlah bangkitan Perjalanan di suatu zona (perjalanan)

$\mathrm{P}=$ Jumlah populasi di suatu zone (orang)

$\mathrm{I}=$ Jumlah pendapatan di suatu zona (Rp. 1.000.000)

$\mathrm{S}=$ Jumlah kepemilikan sepeda motor di suatu zona (sepeda motor)

$\mathrm{M}=$ Jumlah kepemilikan mobil disuatu zona (mobil).

\section{Ukuran Sampel 75\%}

Model bangkitan perjalanan untuk ukuran sampel $75 \%$ berjumlah 26 buah model, dimana ada 20 buah model dengan metode enter dan 6 buah model dengan metode step wise terlihat pada Tabel 5.3. berikut:

Tabel 5.3. Model Bangkitan Perjalanan Yang Terpilih Dengan Sampel 75\%

\begin{tabular}{|c|l|c|c|c|}
\hline No. & \multicolumn{1}{|c|}{ Model Bangkitan Perjalanan } & $\mathbf{R}^{\mathbf{2}}$ & SEE & F \\
\hline 1 & $-3.065+0.641 . \mathrm{P}$ & 0.998 & 6.027 & 3973.300 \\
\hline 2 & $-1.939+0.632 . \mathrm{P}$ & 0.997 & 6.275 & 3312.523 \\
\hline 3 & $-3.298+0.636 . \mathrm{P}$ & 0.997 & 6.688 & 3064.931 \\
\hline 4 & $-2.644+0.633 . \mathrm{P}$ & 0.997 & 6.631 & 3050.680 \\
\hline
\end{tabular}

Populasi dan model yang terbaik adalah model yang pertama yaitu $\mathrm{Y}=-3,065+$ 0,641.P dengan nilai $\mathrm{R}^{2}=0.998, \mathrm{SEE}=6.027$ dan nilai $\mathrm{F}=3973.300$.

\section{Ukuran Sampel 50\%}

Model bangkitan perjalanan untuk ukuran sampel 50\% berjumlah 40 buah model, dimana 30 buah model dengan metode enter dan 10 buah model dengan metode step wise terlihat pada Tabel 5.4 berikut:

Tabel 5.4. Model Bangkitan Perjalanan yang Terpilih dengan Sampel 50\%

\begin{tabular}{|c|l|c|c|c|}
\hline No. & \multicolumn{1}{|c|}{ Model Bangkitan Perjalanan } & $\mathbf{R}^{\mathbf{2}}$ & SEE & F \\
\hline 1 & $-2.051+0.640 . \mathrm{P}$ & 0.998 & 4.272 & 3525.532 \\
\hline 2 & $-2.707+0.645 . \mathrm{P}$ & 0.997 & 4.129 & 3895.753 \\
\hline 3 & $-2.253+0.632 . \mathrm{P}$ & 0.997 & 5.729 & 1812.787 \\
\hline 4 & $-1.342-0.638 . \mathrm{P}$ & 0.997 & 4.851 & 2624.370 \\
\hline 5 & $-0.927+0.626 . \mathrm{P}$ & 0.997 & 4.706 & 2492.130 \\
\hline 6 & $-1.561+0.630 . \mathrm{P}$ & 0.997 & 4.688 & 2597.525 \\
\hline
\end{tabular}


Model yang terbaik adalah model kedua yaitu $\mathrm{Y}=-2,707+0,645 . \mathrm{P}$ dengan nilai $\mathrm{R}^{2}=0.998, \mathrm{SEE}=4.129$ dan nilai $\mathrm{F}=3895.753$

Perhitungan hasil bangkitan perjalanan untuk masing-masing ukuran sampel dan variasinya dapat dilihat pada tabel 5.5 berikut ini:

Tabel 5.5. Hasil Bangkitan Perjalanan

\begin{tabular}{|c|c|c|}
\hline $\begin{array}{c}\text { Ukuran } \\
\text { Sampel }\end{array}$ & $\begin{array}{c}\text { Variasi } \\
\text { Sampel }\end{array}$ & $\begin{array}{c}\text { Hasil Bangkitan } \\
\text { Perjalanan }\end{array}$ \\
\hline $100 \%$ & abcd & 86663,910 \\
\hline $75 \%$ & abc & 87489.707 \\
\hline $75 \%$ & bcd & 86273,215 \\
\hline $75 \%$ & cda & 86804.434 \\
\hline $75 \%$ & dab & 86402.002 \\
\hline $50 \%$ & $\mathrm{ab}$ & 87364,319 \\
\hline $50 \%$ & $\mathrm{ac}$ & 88039,813 \\
\hline $50 \%$ & $\mathrm{ad}$ & 86269,761 \\
\hline $50 \%$ & $\mathrm{bc}$ & 87099,034 \\
\hline $50 \%$ & $\mathrm{bd}$ & 85465,095 \\
\hline $50 \%$ & $\mathrm{Cd}$ & 86004,289 \\
\hline
\end{tabular}

\section{PENGARUH UKURAN SAMPEL TERHADAP MODEL DAN HASIL BANGKITAN PERJALANAN}

\section{Pengaruh Ukuran Sampel Terhadap Nilai Koefisien a, b dan y}

Untuk mengetahui seberapa besar perubahan nilai koefisien a, b dan jumlah bangkitan dari model bangkitan perjalanan yang menggunakan ukuran sampel $75 \%$ dan $50 \%$ terhadap $100 \%$ baik untuk perubahan nilai minimum dan maksimum maupun nilai rata-ratanya, maka dibuat suatu nilai perbandingan seperti yang terlihat pada tabel dibawah ini:

Tabel 5.6. Prosentasi Perbandingan Nilai Koefisien a, b dan bangkitan Untuk Sampel $75 \%$ dibanding $100 \%$

\begin{tabular}{|l|c|c|c|}
\hline \multirow{2}{*}{$\begin{array}{c}\text { Nilai } \\
\text { Prosentasi }\end{array}$} & \multicolumn{2}{|c|}{ Koefisien } & \multirow{2}{*}{$\begin{array}{c}\text { Bangkitan } \\
\text { Perjalanan }\end{array}$} \\
\cline { 2 - 3 } & A & B & \\
\hline Minimum & 10.038 & 0.472 & 0.451 \\
\hline Maksimum & 47.108 & 0.945 & 0.953 \\
\hline Rata-rata & 25.355 & 0.157 & 0.090 \\
\hline
\end{tabular}

\begin{tabular}{|l|c|c|c|}
\hline \multirow{2}{*}{$\begin{array}{c}\text { Nilai } \\
\text { Prosentasi }\end{array}$} & \multicolumn{2}{|c|}{ Koefisien } & \multirow{2}{*}{$\begin{array}{c}\text { Bangkitan } \\
\text { Perjalanan }\end{array}$} \\
\cline { 2 - 4 } & A & B & \\
\hline Minimum & 26.159 & 1.417 & 0.174 \\
\hline Maksimum & 74.714 & 1.575 & 2.177 \\
\hline Rata-rata & 50.709 & 0.026 & 1.128 \\
\hline
\end{tabular}

\section{Uji Statistik Terhadap Nilai Koefisien dan Hasil Bangkitan Perjalanan}

Uji yang cocok digunakan adalah uji Kruskal-Wallis. Untuk menguji hipotesis nol bahwa k

sampel bebas berasal dari populasi yang sama.

$$
\mathrm{H}=\frac{12}{n \cdot(n+1)} \cdot \sum_{i=1}^{k} \frac{r_{1}^{2}}{n_{i}}-3 \cdot(n+1)
$$

Bila $\mathrm{h}$ jatuh dalam daerah kritis $\mathrm{h}>\mathrm{X}_{\alpha}{ }^{2}$ dengan derajat kebebasan $\mathrm{v}=\mathrm{k}-1$, tolak $\mathrm{H}_{0}$ pada taraf keberartian $\alpha$, jika sebaliknya terima $\mathrm{H}_{0}$. Untuk taraf kepercayaan a $=0.05$ dengan nilai $\mathrm{v}=\mathrm{k}-1=1$, diketahui bahwa $\mathrm{X}_{\alpha}{ }^{2}=3,841$. 


\section{PENUTUP}

\section{Kesimpulan}

Berdasarkan hasil pendataan wawancara rumah tangga dan hasil analisis data tersebut, dapat disimpulkan sebagai berikut:

1. Dari hasil perhitungan dengan regresi linear baik untuk ukuran sampel $100 \%$, $75 \%$ dan 50\%, dengan mengukur tingkat koefisien determinasi diperoleh 11 buah model bangkitan perjalanan yang terpilih, yang terdiri dari 1 buah model yang terbaik untuk masing-masing ukuran sampel sebagai berikut:

a. $\mathrm{Y}=-3.666+0.635 . \mathrm{P}$ untuk ukuran sampel $100 \%$

b. $\mathrm{Y}=-3.065+0.641 . \mathrm{P} \quad$ untuk ukuran sampel $75 \%$

c. $\mathrm{Y}=-2,707+0.645 . \mathrm{P} \quad$ untuk ukuran sampel $50 \%$

Semua model bangkitan perjalanan tersebut memberi suatu kesimpulan bahwa pertambahan jumlah populasi akan menyebabkan bertambahnya jumlah bangkitan perjalanan

2. Ukuran sampel mempunyai pengaruh terhadap nilai koefisien model dan hasil bangkitan perjalanan. Semakin sedikit jumlah sampel yang diambil, cenderung menyebabkan bertambahnya nilai koefisien a dan $b$, juga jumlah bangkitan perjalanan.

3. Dengan menggunakan uji non parametrik, yaitu dengan metode KruskalWallis, maka uji tandingan untuk ukuran sampel 100\% dengan $75 \%$ menghasilkan nilai $h_{a}=2 h_{b}=0$ dan $h_{y}=2$, ternyata kurang dari $h_{\text {tabel }}=3.841$, yang membuktikan bahwa rataan nilai koefisien kedua ukuran sampel tersebut adalah sama.

Dan untuk uji tandingan ukuran sampel 100\% dengan 50\% menghasilkan nilai $\mathrm{h}_{\mathrm{a}}$ $=2.25, h_{b}=0$ dan $h_{y}=0$, yang juga membuktikan bahwa rataan nilai koefisien kedua ukuran sampel tersebut adalah sama.

Sedangkan untuk ukuran sampel 75\% dengan 50\%, diperoleh nilai $h_{a}=2.909, h_{b}$ $=0.102$ dan $\mathrm{h}_{\mathrm{y}}=0.182$ yang juga membuktikan bahwa rataan nilai koefisien kedua ukuran sampel tersebut sama.

\section{Saran}

Berdasarkan pada hasil penelitian yang telah dilakukan, maka disarankan untuk penelitian berikutnya yang sejenis dengan penelitian ini untuk melakukan sebagai berikut:

- Jumlah responden dan variabel untuk prediksi model perlu ditambah atau diperbanyak agar variasi model yang terjadi lebih mencerminkan bangkitan perjalanan di kota Rantau.

- Variasi ukuran sampel perlu ditambah untuk dapat melihat dengan lebih teliti pengaruh ukuran sampel tersebut terhadap nilai koefisien model dan hasil bangkitan perjalanan. 


\section{DAFTAR PUSTAKA}

1. Brutton. M.J.(1985), Introduction to Transportation Planning. Hutchinson \& Co Ltd, London.

2. Hobbs, F.D. (1995), Perencanaan dan Teknik Lalu Lintas, Penerbit Gadjah Mada University Press, Yogyakarta.

3. Isya, M (1998), Model Bangkitan Pergerakan Keluarga Dari Zona Perumahan (Studi Kasus Perumahan Kajhu Aceh Besar), Prosiding Simposium I - Forum Studi Transportasi Antar Perguruan Tinggi, Bandung 3 Desember 1998, Institut Teknologi Bandung.

4. Mochammad Sigit, D (1993), Model Bangkitan Lalu Lintas, Studi kasus perumahan Antapani, Kodya Bandung, Tesis S2 Transportasi, Jurusan Teknik Sipil, Institut Teknologi Bandung, Bandung.

5. Pignataro, Louis J., (1973), Traffic Engineering, Theory and Practice, by Prentice-Hall, inc., Englewood Cliffs, New Jersey.

6. Stopher, Peter R (1980), Urban Transportation Modelling and Planning, by D.C Heath and Company, Lexington, Massachusetts, Toronto-London.

7. Tamin, Ofyar Z (2000), Perencanaan dan Permodelan Transportasi, edisi ke-2, Penerbit ITB, Bandung.

8. Walpole Ronald E., and Myer, RH. (1995); Ilmu Peluang dan Statistika untuk Insinyur dan Ilmuwan (terjemahan), edisi ke-4., Penerbit ITB, Bandung. 